\title{
A Study on Some Biological Parameters of Crayfish (Astacus leptodactylus Eschscholtz, 1823) in Ulugöl, Samsun, Turkey
}

\author{
Gülşen Uzun Gören ${ }^{1, a, *}$, Sedat Karayücel ${ }^{1, b}$, İsmihan Karayücel ${ }^{1, c}$ \\ ${ }^{1}$ Faculty of Fisheries and Aquaculture, Sinop University, 57000 Sinop, Turkey. \\ *Corresponding author

A R T I C L E IN F O A B S T R A C T \\ Research Article \\ The study aimed to investigate some morphometric traits, length-weight relationship, meat yield, \\ fecundity and some biochemical compositions of Astacus leptodactylus, in one of the Bafra Fish \\ Lakes named Ulugöl, Samsun, Turkey. A total of 378 A. leptodactylus (198 female and 180 male) \\ were examined. The average carapace length was $50.96 \pm 0.46 \mathrm{~mm}$ for females, $51.31 \pm 0.66 \mathrm{~mm}$ for \\ Received : 03/04/2021 \\ Accepted : 18/06/2021 \\ males and $51.13 \pm 0.40 \mathrm{~mm}$ for all sampled crayfish. Abdomen length was $52.36 \pm 0.49 \mathrm{~mm}$ for \\ females, $49.26 \pm 0.62 \mathrm{~mm}$ for males and $50.87 \pm 0.40 \mathrm{~mm}$ for all sampled crayfish. Live weight was \\ between $14.38 \mathrm{~g}$ and $105.03 \mathrm{~g}$ with an average of $38.26 \pm 0.73 \mathrm{~g}$. The average weight of females was \\ less than that of males. There was a strong relationship between length and weight. The weight of \\ crayfish with pleopodal eggs ranged from $28.24 \mathrm{~g}$, to $59.50 \mathrm{~g}$ with an average of $41.73 \pm 1.09 \mathrm{~g}$. The \\ average number of eggs per individuals was $192.90 \pm 9.94$ with an average number of 4.62 \pm 0.21 per \\ Keywords: \\ Crayfish \\ Astacus Leptodactylus \\ Biological Parameters \\ Meat Yield \\ unit of live weight. The average total egg weight was $3.35 \pm 0.19 \mathrm{~g}$ while the average egg diameter \\ was $2.17 \pm 0.03 \mathrm{~mm}$. Abdomen meat was lower for males comparing with females. Average \\ moisture, crude ash, crude oil and crude protein of abdomen meat were $81.27 \%, 1.47 \%, 0.81 \%$ and \\ $16.45 \%$, respectively.
}

Egg Fecundity

\section{Introduction}

Crayfish are ecological, economically and socially important species. Generally, they are traditionally consumed as a luxury food as well as consumed at special occasions in some countries (Hogger, 1988; Momot, 1995; Harlıoglu and Holdich, 2001). On the other hand, they are a source of protein with low calories and rich for vitamin B, sodium, potassium, calcium and magnesium (Goddard, 1988). Also, crayfish meat has higher content of vitamin $C$ and carotene than many commercial fish species (Harlıoğlu and Köprücü, 2000).

Astacus leptodactylus belonging to Astacidae family naturally exist in Turkey (Holthius, 1961; Geldiay and Kocataş, 1970; Balık et al., 2005). Distribution of two subspecies which generally can be recognizable with the appearance of carapace and chelae (Astacus leptodactylus leptodactylus and Astacus leptodactylus salinus) is reporeted in Turkey (Geldiay and Kocataş, 1970). This species has also been stocked to harvest from natural or artificially created enviroment in a number of countries
(Poland, Italy, Germany, England, Spain and France). In some areas of stocked countries, they formed big population (Köksal, 1988).

Although there are 33 water sources where fishing of crayfish can be done, there is a need for culturing this species under controlled conditions in Turkey (Harlığlu, 2004). Crayfish production reached 5000 tons in the 1980's. After that date, the production has been dramatically decreased because of a kind of fungal (Aphanomyces astaci) shellfish disease called crayfish plague (Bolat, 2001). Production was 696 tons in 2019 (TÜं̇K, 2020).

After crayfish plague occurance in many European countries, studies started to render natural water resources efficiently again by making an attempt to boost the population of Europe's native crayfish species. Therefore, A. astacus and A. leptodactylus known as "Turkish crayfish" became the most important shellfish species used in stocking since A. leptodactylus is more resistant than 
other crayfish species in Europe against the crayfish plague. Besides, the features like high growth rate and reproductive capacity, adapting quickly to the environmental conditions and the similar flavor to $A$. astacus, which is very popular in Europe, have led $A$. leptodactylus to use for stocking (Ingle and Clarke, 1989; Köksal et al., 1992; Harlıoğlu, 2000).

Crayfish stock in Ulugöl, one of the Bafra Fish Lakes, Turkey, is natural and the commercial fishing is based on renting of lakes by commercial enterprises. Since there is no study done in that area before, it is aimed to determine the size of populations, length and weight compositions according to the sex ratio, length-weight relationship, reproduction periods, fecundity, meat yield and biochemical compositions of crayfish, Astacus leptodactylus in this study.

\section{Materials and Methods}

The study was carried out in one of the Bafra Fish Lakes named Ulugöl located in Bafra, Samsun, Turkey. Ulugöl is located in Kızılırmak Delta and coordinated with $41^{\circ} 36^{\prime} \mathrm{N} ; 36^{\circ} 04^{\prime} \mathrm{E}$ showing a lagoon character with 1389 ha area (Figure 1). Ulugöl, having prime importance for fishing, has an average depth of $1.5 \mathrm{~m}$.

The A. leptodactylus samples used in this study were choosen randomly among healthy population, caught with pinter nets by fishermen monthly between July 2010 and July 2011. A total of 378 crayfishes (f:m 1:0,91) were used in the study.

The samples were brought to a laboratuar in Faculty of Aquaculture, University of Sinop with a humidified styropor container. Morphometric measurements were done according to Rhodes and Holdich (1984). After sexing of the samples, total length, carapace length, carapace width, abdomen length, abdomen width, chelae length and chelae width were measured with a digital caliper to the nearest $0.1 \mathrm{~mm}$ whereas their weights were measured with a sensitive scale to the nearest $0.001 \mathrm{~g}$ (Figure 2). In order to determine the abdomen meat yield, the whole samples were boiled for 10 minutes in water, their abdomens were cut and fleshs were taken with a clip and then they were weighed with the sensitive scale.

In order to determine the biochemical composition, abdomens of the crayfish were removed and stored $-80^{\circ} \mathrm{C}$. Crude protein analyze was done according to Kjeldahl method (AOAC, 1980), crude oil analyze was done according to Soksalet method by using Gerhard brand device and moisture, ash and dry matter analyses were done according to AOAC, 1990 with three paralels.

Eggs adhered to pleopods of crayfish were taken out without giving any damage by a clip and weighthed in a tared container with the sensitive scale for determination of the fecundity. After completion of the weighing operation, the whole eggs taken from each female were counted in a separate container and their diameters were measured with a sensitive electronical caliper to the nearest $0.01 \mathrm{~mm}$.

Regression analyses were performed for the relationships between morphometric parameters. Relations between parameters related to fecundity were evaluated by correlation analysis. Microsoft Office Excel 2003 and Minitab 13.1 software programs were used for the statistical analysis.

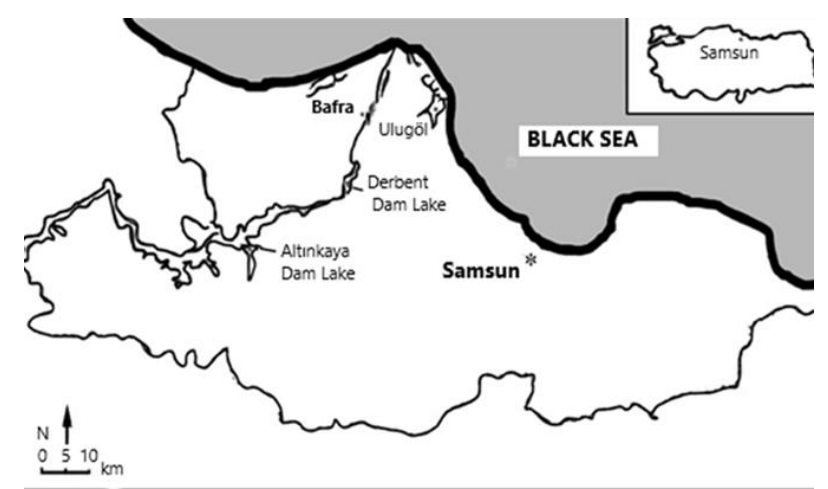

Figure 1. Research area

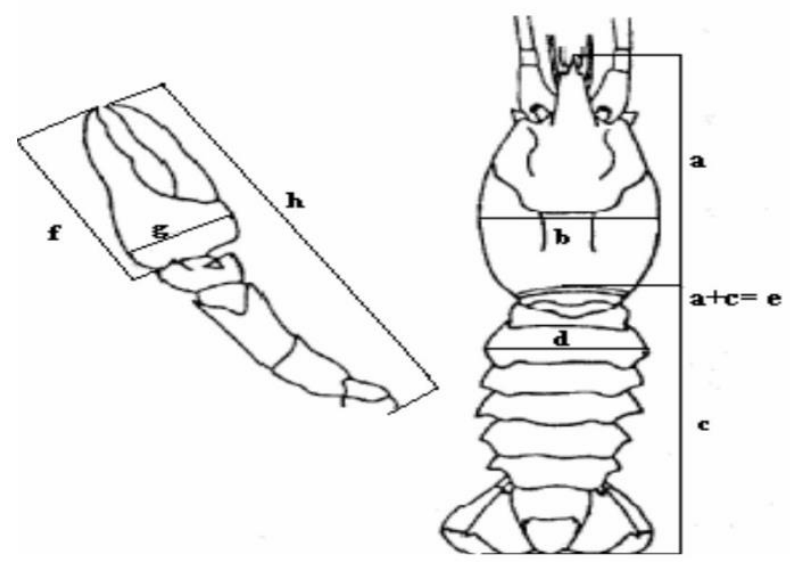

Figure 2. Particular measurements relating to the body portion of crayfish (Rhodes and Holdich, 1984).

a) carapace length b) carapace width c) abdomen length d) abdomen width e) total length $f$ ) chelae length g) chelae width and h) chelae foot length.

\section{Results}

A total of 378 A. leptodactylus (198 female and 180 male) were examined and there were no significant differences in sex ratio according to the months $(\mathrm{P}>0.05)$.

Total length and carapace length of crayfishes were ranged between $80-156 \mathrm{~mm}$ and $22-83 \mathrm{~mm}$, respectively. Average carapace length in females, in males and in all samples were $50.96 \pm 0.46 \mathrm{~mm}$ (min: $30.66 \mathrm{~mm}$, max: 82.03 $\mathrm{mm}), 51.31 \pm 0.66 \mathrm{~mm}$ (min: $22.17 \mathrm{~mm}$, $\max : 78.28 \mathrm{~mm}$ ) and $51.13 \pm 0.40 \mathrm{~mm}$, respectively. The average length of the abdomen of females was $52.36 \pm 0.49 \mathrm{~mm}$, whereas it was $49.26 \pm 0.62 \mathrm{~mm}$ in males with an average of $50.87 \pm 0.40 \mathrm{~mm}$ for all speciments. The abdomen length of females $(24.00 \pm 0.23 \mathrm{~mm})$ was significantly higher that of males $(20.48 \pm 0.23 \mathrm{~mm}, \mathrm{P}<0.001)$.

In addition, carapace length, chelae length and width of males were significantly higher when compared with females $(\mathrm{P}<0.001)$. The weight of crayfish samples changed between $14.38-105.03 \mathrm{~g}$ and the average weight was $38.26 \pm 0.73 \mathrm{~g}$. The average weight of females $(35.63 \pm 0.73 \mathrm{~g})$ was less than that of males $(41.12 \pm 1.27 \mathrm{~g})$ $(\mathrm{P}<0.05)$.

Length-weight relationship (r) was 0.91 for all individuals whereas it was 0.93 for only females and males (Figure 3). 

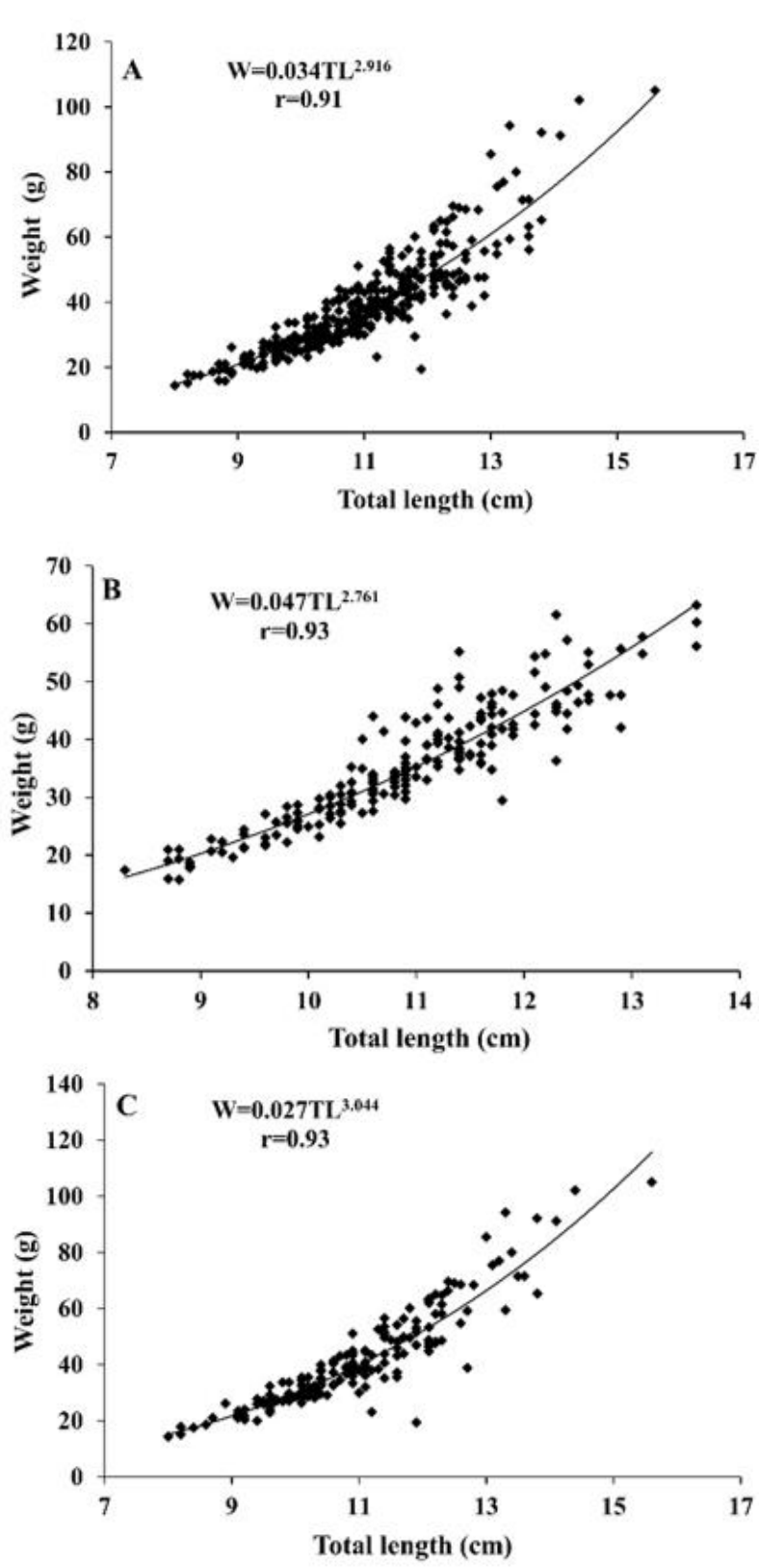

Figure 3. Total length-weight relationship of female+male A. leptodactylus (A), females (B) and males (C).

The average weights of abdomen meat were $3.59 \pm 0.13$ and $3.49 \pm 0.14 \mathrm{~g}$ for females and males, respectively and there was no significant difference between them $(\mathrm{P}>0.05)$. The average abdomen meat yields were $9.43 \pm 0.79 \%$ in females and $9.57 \pm 0.95 \%$ in males. The difference was not significant in terms of abdomen meat yield between male and female crayfish $(\mathrm{P}>0.05)$.

Table 1. shows the correlation values and regression equations of total weight, total egg weight, the number of eggs per unit of live weight in crayfish.

The minimum, maximum and the average weight of crayfishes with pleopodal eggs were 28.24, 59.50 and $41.73 \pm 1.09 \mathrm{~g}$, respectively. The average egg number of indivudual crayfish was $192.90 \pm 9.94$ (maximum 368, minimum 50 eggs). The number of eggs for per unit of live weight was $4.62 \pm 0.21$. The average total egg weight was $3.35 \pm 0.19 \mathrm{~g}$. The average diameter of 9645 eggs was $2.17 \pm 0.03 \mathrm{~mm}$.
Significant relationships between total weight-total egg weight $(\mathrm{r}=0.74)$ and total weight- total egg number $(r=0.50)$, total egg weight-total egg number $(r=0.72)$, total egg number-the number of eggs for per unit of live weight $(\mathrm{r}=0.86)$ were determined $(\mathrm{P}<0.05)$ (Figure 4$)$.

Positively, but non-significant relationships between total weight-the number of eggs for per unit of live weight $(\mathrm{r}=0.01)$ and total weight-egg diameter $(\mathrm{r}=0.21)$, total egg weight-the number of eggs for per unit of live weight $(\mathrm{r}=0.43)$ and total egg weight-egg diameter $(\mathrm{r}=0.27)$, total egg number-egg diameter $(\mathrm{r}=0.20)$ and egg diameter-the number of eggs for per unit of live weight $(\mathrm{r}=0.14)$ were detected.

Average moisture, crude ash, crude oil and crude protein were $81.27 \pm 0.36 \%, 1.47 \pm 0.14 \%, \quad 0.81 \pm 0.04 \%$, $16.45 \pm 0.36 \%$ respectively (Table 2 ).

\section{Discussion}

In studies comparing of different lengths and weights of body parts of male and female crayfish species, it was reported that generally body weight of males is higher than that of females and abdomens of females are longer and wider than males whereas chelae and chelae feet of males are longer and chelae of males also are wider than that of females (Stein, 1976; Rhodes and Holdich, 1979; Lindqvist and Lahti, 1983; Huner et al., 1991; Harlıoğlu, 2000). In the present study, male A. leptodactylus was heavier than females, chelae length and width were longer than females but abdomens of females were wider and longer with a similarity of previous studies. Balık et al. (2005) reported that the highest ratio value of $22.25 \%$ was between 18.5 $23.4 \mathrm{~g}$ weight ranges of $A$. leptodactylus population at Demirköprü Reservoir. Female individuals with $28.32 \%$ ratio were in 23.5-28.4 g weight group while males with $\% 19.74$ ratio was in $18.5-23.4 \mathrm{~g}$ as the highest density. Güner (2006) determined that the average weight and average length of A. leptodactylus in Terkos Lake were $52.25 \mathrm{~g}$ and $121.33 \mathrm{~mm}$, respectively.

Dartay and Ateşşahin (2013) reported that the average length and weight of male and female A. leptodactylus were $112.93 \mathrm{~mm}$ and $50.32 \pm 4.34 \mathrm{~g}$ and $100.38 \mathrm{~mm}$ and $35.82 \pm 5.76 \mathrm{~g}$, respectively. Considering the average length and weight values of crayfish, this study showed a similarity and also differences with the findings of other researchers. When all studies were analysed, there are differences between the values obtained by several researchers of the same lake in length and weight distribution. Similarly, differences were observed between the values that the same researcher obtained in different lakes or in the same lake with different times. The reasons for these differences might be the occurrence of crayfish with different lengths at different depths and at different base structures in different seasons, the different hunting methods and the effect of hunting pressure in some lakes.

There were no significant differences in sex ratio of $A$. leptodactylus in the present study. The sex raito of $A$. leptodactylus was $47 \%$ male and 53\% female in Eğirdir Lake and $48 \%$ male and $52 \%$ female in Terkos Lake (Köksal, 1980). 54\% female and $46 \%$ male of $A$. leptodactylus in Apa Dam Lake and 61\% female and 39\% male of A. leptodactylus in Eğirdir Lake were reported by Erdemli (1983). 
Table 1. Correlation values and regression equations of total weight, total egg weight, the number of eggs per unit of live weight in A. leptodactylus (TW: Total-weight, TWE: Total weight of eggs, TNE: Total number of eggs, ED: Egg diameter, NEPULW: The number of eggs for per unit of live weight).

\begin{tabular}{l|ccccc}
\hline \multicolumn{5}{c}{ Correlation value and regression equations } \\
\hline TW & TW & TWE & TNE & ED & NEPULW \\
TWE & & $\mathrm{y}=0.127 \mathrm{x}-1.951$ & $\mathrm{y}=4.647 \mathrm{x}-1.063$ & $\mathrm{y}=-0.038 \mathrm{x}+3.983$ & $\mathrm{y}=0.004 \mathrm{x}+4.442$ \\
TNE & 0.74 & & $\mathrm{y}=38.76 \mathrm{x}+63.15$ & $\mathrm{y}=-0.287 \mathrm{x}+3.333$ & $\mathrm{y}=0.497 \mathrm{x}+2.950$ \\
ED & 0.50 & 0.72 & 0.20 & $\mathrm{y}=-0.004 \mathrm{x}+3.145$ & $\mathrm{y}=0.018 \mathrm{x}+1.052$ \\
NEPULW & 0.21 & 0.27 & & & $\mathrm{y}=0.153 \mathrm{x}+4.980$ \\
\end{tabular}

Table 2. Monthly distribution of average moisture, crude ash, crude oil and crude protein during experimental period in A. leptodactylus.

\begin{tabular}{l|cccc}
\hline \multicolumn{1}{c|}{ Monthly } & Moisture (\%) & Crude ash (\%) & Crude oil (\%) & Crude protein (\%) \\
\hline July & $81.98 \pm 0.58$ & $1.37 \pm 0.11$ & $0.41 \pm 0.02$ & $16.24 \pm 0.34$ \\
August & $82.68 \pm 0.39$ & $1.56 \pm 0.13$ & $0.46 \pm 0.03$ & $15.28 \pm 0.51$ \\
September & $83.17 \pm 0.18$ & $1.62 \pm 0.09$ & $0.54 \pm 0.07$ & $14.66 \pm 0.06$ \\
October & $82.96 \pm 0.17$ & $1.56 \pm 0.20$ & $0.60 \pm 0.02$ & $14.87 \pm 0.44$ \\
November & $83.33 \pm 0.05$ & $1.51 \pm 0.27$ & $0.51 \pm 0.00$ & $14.64 \pm 0.47$ \\
December & $81.90 \pm 0.37$ & $1.42 \pm 0.15$ & $0.41 \pm 0.02$ & $16.27 \pm 0.11$ \\
January & $78.82 \pm 0.54$ & $1.21 \pm 0.27$ & $1.58 \pm 0.09$ & $18.38 \pm 1.10$ \\
February & $79.63 \pm 0.20$ & $1.27 \pm 0.02$ & $1.54 \pm 0.03$ & $17.56 \pm 0.24$ \\
March & $82.93 \pm 0.15$ & $1.18 \pm 0.07$ & $0.44 \pm 0.02$ & $15.44 \pm 0.22$ \\
April & $79.19 \pm 0.39$ & $1.54 \pm 0.02$ & $1.49 \pm 0.04$ & $17.79 \pm 0.09$ \\
May & $79.35 \pm 0.41$ & $1.99 \pm 0.16$ & $0.42 \pm 0.04$ & $18.24 \pm 0.51$ \\
June & $78.12 \pm 0.36$ & $1.31 \pm 0.02$ & $1.75 \pm 0.03$ & $18.82 \pm 0.14$ \\
July & $82.25 \pm 0.53$ & $1.57 \pm 0.13$ & $0.45 \pm 0.02$ & $15.73 \pm 0.08$ \\
Average & $81.27 \pm 0.36$ & $1.47 \pm 0.14$ & $0.81 \pm 0.04$ & $16.45 \pm 0.36$ \\
\hline
\end{tabular}
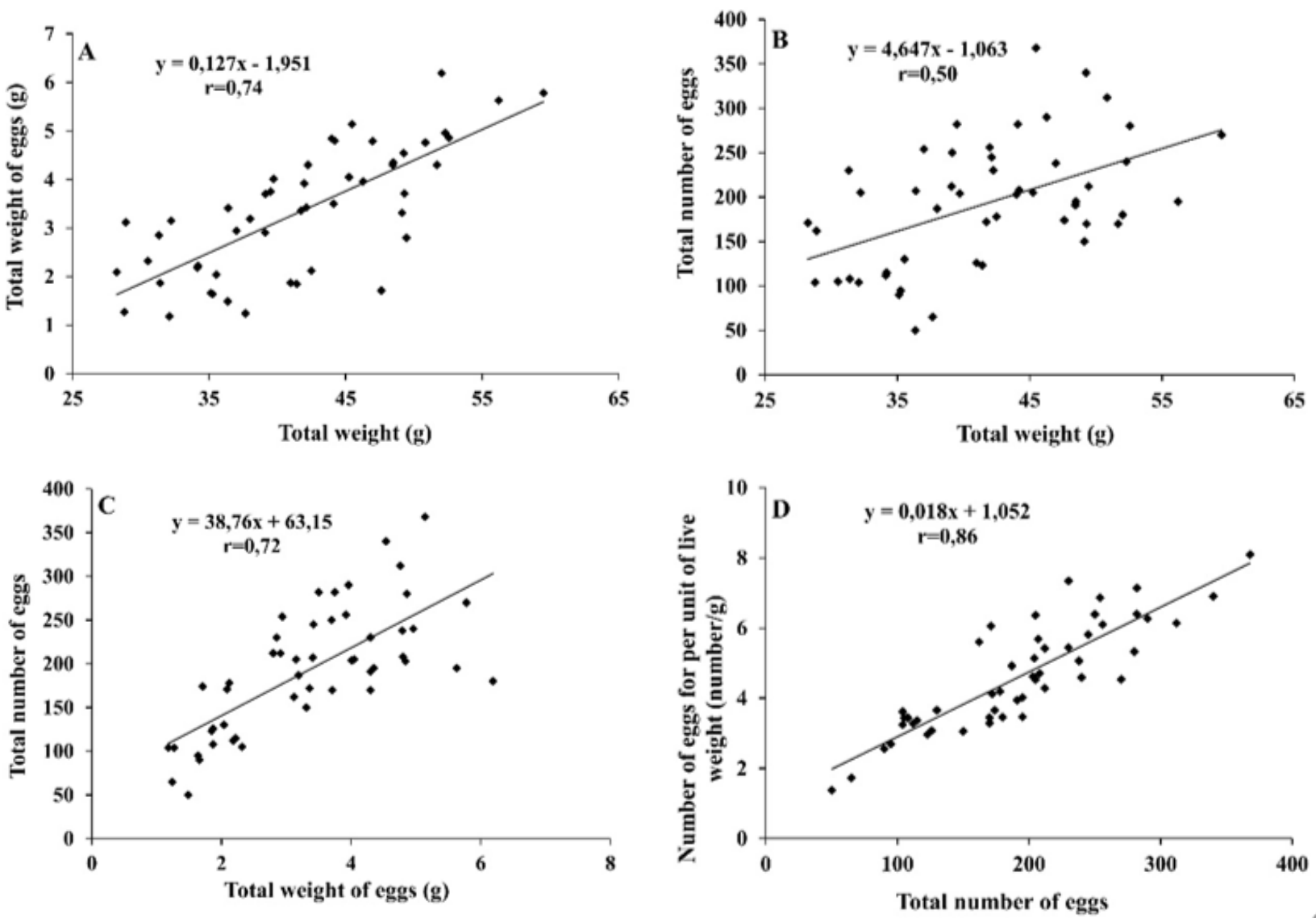

Figure 4. Total weight-total weight of eggs (A), Total weight-total number of eggs (B), Total weight of eggs-total number of eggs (C), Total number of eggs-number of eggs for per unit of live weight (D) in A. leptodactylus. 
The average female and male A. leptodactylus ratio were $47 \%$ and $53 \%$, respectively from seven inland waters: Avşar Dam Lake, Çıldır Lake, Eğirdir Lake, Hirfanlı Dam Lake, Keban Dam Lake, Porsuk Dam Lake and Karpuzlu Pond (Bök et al., 2013). Dartay and Ateşşahin (2013) reported that $42 \%$ female and $58 \%$ male A. leptodactylus in Keban Dam Lake, Pertek region. Maguire and Dakic (2011) found $41 \%$ female and 59\% male A. leptodactylus in Croatia and Armenia. Results obtained from the present study showed similarity with the study of Köksal (1980) for Terkos Lake and Erdemli (1983) for Egirdir Lake. The values obtained from the other studies are very different. The reason of this difference could be resulted from that because females in spawning period carry eggs under abdomens, they cannot be active as male crayfish and they may not show interest to eel-buck as much as male crayfishes. So, it is thought that the hunting season and even the different hours of day of catching time might have an effect on sex ratio of caught individuals.

In this research, a strong linear relationship between length and weight was found. A negative allometric growth was detected in female and in male + female $A$. leptodactylus (b values for female and male + female crayfish were $2.76,2.92$, respectively). There was a positive allometric growth in male crayfish (b value was 3.04). A negative allometric growth in male and female $A$. leptodactylus was reported by Harlığlu (1999) in Keban Dam Lake and Bolat (2001) in Eğirdir Lake. A positive allometric growth in male A. leptodactylus in Demirköprü Dam Lake (Balık et al., 2005) and in Sera Lake (Erkebay, 2004) was also reported. A positive allometric growth in male (b value was 3.01) and a negative allometric growth in female (b value was 2.33) were detected in $A$. leptodactylus from Keban Dam Lake by Dartay and Ateşşahin (2013). Despite the livings grow in length during development, weight growth rate is influenced by genetic structures and ecological factors which have great effect on food quality and quantity. So, in the present study, growth characteristics and regression equations obtained in the length-weight relationship are the natural results and they could be similar or different according to region and period which data was obtained.

In the present study, the average abdomen meat amount was $3.49 \pm 0.14 \mathrm{~g}$ in male and $3.59 \pm 0.13 \mathrm{~g}$ in female $A$. leptodactylus and it was not differed significantly between both sexes $(\mathrm{P}>0.05)$. Yildirım et al. (1995) found this value as $3.0 \pm 0.5 \mathrm{~g}$ for boiled male and female A. leptodactylus in the length group of 90 to $100 \mathrm{~mm}$ caught from Lake Eğirdir. Harlıoğlu (1999) reported that the abdomen meat amount of male and female A. leptodactylus obtained from Keban Dam Lake after cooked for 10 minutes were $3.72 \pm 0.75 \mathrm{~g}$ ve $3.47 \pm 0.55 \mathrm{~g}$, respectively in $46-58 \mathrm{~mm}$ carapace length-group and there were no significant differences between the sexes in terms of abdomen meat yield. The abdomen meat amounts of female and male $A$. leptodactylus were ranged between $8.97-10.23 \%$ and 7.34$8.67 \%$, respectively in Kardshali Lake (Bulgaria) (Hubenova et al., 2004). The findings of the present study related to abdomen meat amount show similarity to the findings of the above researches.

Average abdomen meat yield was $9.43 \pm 0.79 \%$ in females and $9.57 \pm 0.95 \%$ in males in the present study. No notable difference was found between male and female crayfish $(\mathrm{P}>0.05)$ in terms of abdomen flesh yield. Similarly, there was no significant difference in abdomen meat weights of male and female A. leptodactylus in Keban Dam Lake, in Çemişgezek Location (Barım, 2007). The reason for findings of diverse results for the same species in meat yield studies might depend on the population, catching time, boiling time of the sample, the way of removing the flesh and length group of samples.

The average weight of crayfish with pleopodal eggs was $41.73 \pm 1.09 \mathrm{~g}$ in this study. The average individual number of eggs of crayfish with eggs was $192.90 \pm 9.94$ while number of eggs for unit weight was $4.62 \pm 0.21$. Total egg weight was $3.35 \pm 0.19 \mathrm{~g}$. The average egg diamter was $2.17 \pm 0.03 \mathrm{~mm}$. Average total weights of in $A$. leptodactylus with pleopodal eggs were $31.72 \mathrm{~g}$ in Iş1klı Lake (Güner and Balık, 2002), $32.19 \mathrm{~g}$ in Mamasın Dam Lake (Büyükçapar et al., 2006) and $40.38 \mathrm{~g}$ in Terkos Lake (Güner, 2006). The findings of the present study show similarity with the values of the above studies.

The average numbers of eggs in A. leptodactylus were 154 in İznik Lake (Erdem et al., 2001), 216 in Işıklı Lake (Güner and Balık, 2002), 137 in Demirköprü Dam Lake (Balık et al., 2005), 200 in Eğirdir Lake (Mişe Yonar et al., 2017), 240 in Hirfanlı Dam Lake (Cilbiz, 2020), 314 in Dluzek Lake (Polland) and 374 in Mazurian Lake (Polland) (Stypnsk, 1979). The number of eggs varied from 50 to 368 with an average of $192.90 \pm 9.94$ in the present study and it was mostly similar with the others but might be higher than the values provided from other studies.

The average egg diameters of A. leptodactylus was 2.77 $\mathrm{mm}$ in Eğirdir Lake (Bolat, 2001), 2.15-2.99 mm in Iş1kl1 Lake (Güner and Balık, 2002) and $2.72 \mathrm{~mm}$ in Demirköprü Barrage Lake (Balık et al., 2005). The average diameter of egg with $2.17 \pm 0.03 \mathrm{~mm}$ in this study was lower than the other studies in different regions. It was reported that egg diameter is under the effect of a number of factors and it has a weak relationship with morphometric data in the studies about the crayfish (Harlıoğlu and Türkgülü, 2000; Güner and Balık, 2002; Demirol et al., 2017; Cilbiz, 2020). It was pointed out that egg yield is controlled by genetic factors rather than echologic ones (Erdemli, 1985) or there are other factors which influence the productivity (Güner and Balık, 2002).

Chemical compositions of crayfish included $81.27 \pm 0.36 \%$ moisture, $1.47 \pm 0.14 \%$ crude ash, $0.81 \pm 0.04 \%$ oil and $16.45 \pm 0.36 \%$ crude protein in the present study. İlhan and Şahin (2006) reported that $A$. leptodactylus in Büyükçekmece Lake consisted of 83.01\% moisture, $0.62 \%$ crude oil, $1.46 \%$ crude ash and $14.17 \%$ crude protein. A study was conducted by Bilgin et al. (2008) in order to determine some nutrional compenents of A. leptodactylus in Eğirdir Lake according to their length group and sex. The moisture, crude protein, crude oil and crude ash contents were 78.25 and $80.75 \%, 15.77$ and $17.65 \%, 1.48$ and $1.96 \%$ and 1.15 and $1.45 \%$, respectively, in male and female in 8-13.9 cm length group. The findings obtained in this study showed similarity to the findings obtained from the other studies.

\section{Conclusion}

It could be concluded that there is a healthy catchable stock of A. leptodactylus in Ulugöl and it is thought that studies about morphologic characteristics of the 
population, length-weight relationships between sexes, length and weight relationships, reproduction periods, fecundity, meat yield and biochemical composition could be useful to observe possible differences year by year and guide to be applied effective fishing strategies. Also, the evaluation of the population parameters of the freshwater lobster is of great importance in terms of maintaining the population balance in the ecosystem and providing outputs for growing it in culture conditions. It is thought that the data to be obtained from local studies on the current status of crayfish stocks will help to culture the crayfish.

\section{References}

AOAC, 1980. Official methods of analysis, 13th ed. Association of Official Analytical Chemists. Washington D.C, 376-384 pp.

AOAC, 1990. Official methods of analysis. 15th. Edition. Heldrich, K. (ed) Association of Official Analytical Chemists. Arlington, Virginia. U.S.A. 1298 p.

Balık S, Ustaoğlu MR, Sarı MH, Berber S. 2005. Determination of traits some growth and morphometric of crayfish (Astacus leptodactylus Eschscholtz, 1823) at Demirköprü Dam Lake (Manisa). Ege Üniversitesi Su Ürünleri Dergisi. 22(1-2): 83-89.

Barım Ö. 2007. Morphometric analysis and meat yield of freshwater crayfish, Astacus leptodactylus Eschscholtz, 1823, in Çemisgezek Region of Keban Dam Lake Science and Eng. Journal of Firat Univ. 19(3): 301-307.

Bilgin Ş, İzci L, Günlü A, Bolat Y, Diler A. 2008. Determination of some food components according to length groups and sex of freshwater crayfish (Astacus leptodactylus Esch, 1823) in Eğirdir Lake Biyoloji Bilimleri Araştırma Dergisi, 1(2): 57-62.

Bolat Y. 2001. Estimation of population size of freshwater lobsters (Astacus leptodactylus salinus Nordmann, 1842) in Lake Eğirdir Hoyran Region. PhD Thesis, Süleyman Demirel University Institute of Science, Isparta, 116.

Bök TD, Aydın H, Ateş C. 2013. A study on some morphological characteristics of Astacus leptodactylus (Eschscholtz 1823) in seven different inland waters in Turkey J. Black Sea/Mediterranean Environment Vol. 19, Issue. 2: 190-205.

Büyükçapar H, Alp A, Kaya M, Çiçek Y. 2006. The lengthweight relationships and meat yield of crayfish (Astacus leptodactylus Eschscholtz, 1823) in the Mamasin Reservoir (Aksaray, Turkey). E.U. Journal of Fisheries and Aquatic Sciences Volume 23, Issue (1-2): 21-25.

Cilbiz M. 2020. Pleopodal fecundity of narrow-clawed crayfish (Pontastacus leptodactylus Eschscholtz, 1823), Invertebrate Reproduction Development, 64(3): 208-218.

Dartay M, Ateşşahin T. 2013. A study on catching freshwater crayfish, Astacus leptodactylus Eschscholtz 1823, and its some population characteristics Turkish Journal of Science and Technology Volume 8(2): 125-130.

Demirol F, Gündüz F, Yüksel F, Güler M, Beri A, Yıldırım T. 2017. The investigation on reproduction characteristics of crayfish (Astacus leptodactylus Eschscholtz, 1823) in the Keban Dam Lake. Yunus Araştırma Bülteni, 2: 125-136.

Erdem Ü, Cebeci M, Selçuk S, Tunç N, Özbay A, Çildem B. 2001. Some bio-ecologic features of crayfish (Astacus leptodactylus Eschscholtz, 1823) in İznik Lake. XI. Ulusal Su Ürün Semp; 04-06 Eylül 2001; Hatay, pp. 449-456.

Erdemli AÜ. 1983. A comparative study on populations of freshwater lobsters (Astacus leptodactylus Eschscholtz, 1823) in Beyşehir, Eğirdir, Akşehir and Apa Dam Lake, Journal of Nature Science, 7: 313-318.

Erdemli AÜ. 1985. A research on some biological and morphological characteristics of freshwater lobster (Astacus leptodactylus salinus Nordmann, 1842) populations in Hotamış Lake and Mamasın Dam Lake. Scientific Research Council of Turkey Mathematics, Physics and Biology Research Group, Project No: TBAG 594: 73 p.
Erkebay C. 2004. Biological characteristics of Sera Lake (Trabzon) crayfish (Astacus leptodactylus) stock, stock structure and breeding opportunities under Eastern Black Sea conditions, KTU Institute of Science, Department of Fisheries Technology Engineering, PhD Thesis, 70.

Geldiay R, Kocataş A. 1970. The preliminary report about the taxonomy and distribution of Astacus (Decapoda) of Turkey. Ege Üniversitesi Fen Fakültesi İlmi Raporlar Serisi, Ege Üniversitesi Matbaas1, Yayın No: 94: $12 \mathrm{~s}$.

Goddard JS. 1988. Food and feeding. In: Freshwater Crayfish: Biology, Management and Explotation. Chapman and Hall, London, $448 \mathrm{p}$.

Güner U. 2006. Some morfometric characteristics of crayfish (Astacus leptodactylus Eschscholtz, 1823) in Lake Terkos. E.U. Journal of Fisheries and Aquatic Sciences Cilt/Volume 23, Say1/Issue (1-2): 163-167.

Güner U, Balık S. 2002. Relationship between length-weight and egg productivity of crayfishes (Astacus leptodactylus Eschscholtz, 1823) in Lake Işıklı (Çivril-Denizli). E.U. Journal of Fisheries and Aquatic Sciences Cilt/Volume 19, Say1/Issue (1-2): 109-113.

Harlığlu MM, Köprücü K. 2000. An investigation on the vitamin $\mathrm{A}_{2}, \mathrm{C}, \mathrm{E}$ and $\beta$-carotene contents of freshwater crayfish, (Astacus leptodactylus Eschscholtz, 1823) Frrat Üniversitesi Fen ve Mühendislik Bilimleri Dergisi, 12(2): 277-281.

Harlığlu MM. 1999. The relationships between length-weight, and meat yield of freshwater crayfish, Astacus leptodactylus Eschcholtz, in the Ağın region of Keban Dam Lake Turk Zooloji, 23: 949-957.

Harlığlu MM. 2000. Comparison of the chelipeds of two crayfish species, Astacus leptodactylus Eschscholtz, 1823 and Pacifastacus leniusculus (Dana) Ege Üniversitesi Su Ürünleri Dergisi 17(1-2): 47-56.

Harlıoğlu MM, Holdich DM. 2001. Meat yields in the introduced crayfish, Pacifastacus leniusculus and Astacus leptodactylus, from British waters, Aquaculture Research, 32:411-417.

Harlığlu MM, Türkgülü İ. 2000. The relationship between egg size and female size in freshwater crayfish, Astacus leptodactylus. Aquaculture International, 8: 95- 98.

Harlıoglu MM. 2004. The present situtation of freshwater crayfish, A. leptodactylus (Eschscholtz, 1823) in Turkey. Aquaculture 230: 181-187.

Hogger JB. 1988. Ecology Population Biology and Behaviour, Freshwater Crayfish, Biology, Management and exploitation, Cambridge, $512 \mathrm{p}$.

Holthius JV. 1961. Report on a collection of Crustacea, Decapoda and Stomatopoda from Turkey and Balkans, Zoologiche Verhandelingen, 47: 1-30.

Hubenova T, Zaikov A, Vassileva P. 2004. Investigations into the amount of meat (Astacus leptodactylus Eschscholtz, 1823), Fischer and Teichwirt 6:690-692.

Huner JV, Henttonen P, Lindqvist OV. 1991. Lenght-lenght and lenght-weight characterizations of noble crayfish, Astacus astacus L. (Decapoda, Astacidae), from central Finland, Journal of Shellfish Research, 10(1): 195-196.

Ingle RW, Clarke PF. 1989. Turkish crayfish thrive in a London canal. The London Naturalist 68: 73-75.

İlhan RE, Şahin SK. 2006. Effect of breeding period on meat yield and chemical composition of crayfish (Astacus leptodactylus, Eschscholtz, 1823). Journal of Fisheries Engineers Association, 32: 45-47.

Köksal G. 1980. Biometric analysis on the freshwater crayfish (Astacus leptodactylus Eschscholtz, 1823) which is produced in Turkey, relationship between the major body components and meat yield, Ankara Üniversitesi Veteriner Fakültesi Dergisi, 26(3-4): 93-114.

Köksal G. 1988. Astacus leptodactylus in Europe. In: Freshwater Crayfish: Biology, Management and Exploitation, Croom Helm, London and Timber Press, Oregon, 365-400. 
Köksal G, Ölmez M, Bekcan S, Güler AS. 1992. Juvenile breeding of freshwater lobster (Astacus leptodactylus Eschscholtz, 1823) for restoration of natural waters. Istanbul University, Journal of Fisheries, 1: 1-16.

Lindqvist OV, Lahti E. 1983. On the sexuel dimorphism and condition indexs in the crayfish Astacus astacus L. İn Finland, Freshwater Crayfish 5: 3-11.

Maguire AI, Dakic L. 2011. Comparative analyses of Astacus leptodactylus morphological characteristics from Croatia and Biologia 66/3: 491-498, Section Zoology doi: 10.2478/s11756-011-0045-y.

Mişe Yonar S, Köprücü K, Enis Yonar M, Silici S. 2017. Effects of dietary propolis on the number and size of pleopadal egg, oxidative stress and antioxidant status of freshwater crayfish (Astacus leptodactylus Eschscholtz, 1823). Animal Reproduction Science, 184: 149-159.

Momot WT. 1995. Redefining the role of crayfish in aquatic ecosystems. Review of Fisheries Science, 3: 33-63.
Rhodes CP, Holdich DM. 1979. On size and sexuel dimorphism in Austropotamobius pallipes (Lereboullet) A step in assessing the commercial exploitation potential of the native British freshwater crayfish, Aquaculture, 17: 345-358.

Rhodes CP, Holdich DM. 1984. Length-weight relationship, muscle production and proximate composition of the freshwater crayfish Austropotamobius pallipes (Lereboullet). Aquaculture 37, 107: 123.

Stein RA. 1976. Sexual dimorphizm in crayfish chelae: Functional significance linked to reproductive activites, Can. J. Zool. 54: 220-227.

Stypnsk M. 1979. Comparison of the species fecundity of crayfishes inhabiting waters of the Mazurian Lakeland. Zoologica Poloniae 27: 279- 289.

TUIK, 2020. Turkish Statistical Institute. http://www.tuik. gov.tr cited 5 October 2020.

Yıldırım MZ, Gülyavuz H, Ünlüsayın M. 1995. A study on meat yield of Lake Eğirdir crayfish (Astacus leptodactylus salinus, Nordmann, 1842). Turkish Journal of Zoology, 21: 101-105. 